\title{
Endogenous Kisspeptin Tone Is a Critical Excitatory Component of Spontaneous GnRH Activity and the GnRH Response to NPY and CART
}

\author{
Saurabh Verma ${ }^{a}$ b Melissa A. Kirigitia ${ }^{a}$ Robert P. Millar ${ }^{c}$ Kevin L. Grove ${ }^{a}$ \\ M. Susan Smith ${ }^{a}$ \\ ${ }^{a}$ Division of Diabetes, Obesity, \& Metabolism, Oregon National Primate Research Center, Oregon Health \& \\ Sciences University, Beaverton, Oreg., and ${ }^{b}$ College of Veterinary Medicine, lowa State University, Ames, lowa, USA; \\ 'MRC Receptor Biology \& Reproductive Health, University of Pretoria, Pretoria, South Africa
}

\section{Key Words}

Gonadotropin-releasing hormone $\cdot$ Kisspeptin ·

Electrophysiology · Cocaine- and amphetamine-regulated transcript $\cdot$ Neuropeptide $Y$

\begin{abstract}
Background/Aims: Kisspeptin is the major excitatory regulator of gonadotropin-releasing hormone $(\mathrm{GnRH})$ neurons and is responsible for basal GnRH/LH release and the $\mathrm{GnRH} / \mathrm{LH}$ surge. Although it is widely assumed, based on mutations in kisspeptin and Kiss1R, that kisspeptin acts to sustain basal GnRH neuronal activity, there have been no studies to investigate whether endogenous basal kisspeptin tone plays a direct role in basal spontaneous $\mathrm{GnRH}$ neuronal excitability. It is also of interest to examine possible interactions between endogenous kisspeptin tone and other neuropeptides that have direct effects on $\mathrm{GnRH}$ neurons, such as neuropeptide Y (NPY) or cocaine- and amphetamine-regulated transcript (CART), since the activity of all these neuropeptides changes during states of negative energy balance. Methods: Loose cell-attached and whole-cell current patch-clamp recordings were made from GnRH-GFP neurons in hypothalamic slices from female and male rats. Results: Kisspeptin activated GnRH neurons in a concentration-dependent manner with an $\mathrm{EC}_{50}$ of $3.32 \pm 0.02 \mathrm{nM}$. Surprisingly, a kisspeptin an-
\end{abstract}

tagonist, Peptide 347, suppressed spontaneous activity in $\mathrm{GnRH}$ neurons, demonstrating the essential nature of the endogenous kisspeptin tone. Furthermore, inhibition of endogenous kisspeptin tone blocked the direct activation of GnRH cells that occurs in response to antagonism of NPY Y5 receptor or by CART. Conclusions: Our electrophysiology studies suggest that basal endogenous kisspeptin tone is not only essential for spontaneous GnRH neuronal firing, but it is also required for the net excitatory effects of other neuropeptides, such as CART or NPY antagonism, on GnRH neurons. Therefore, endogenous kisspeptin tone could serve as the linchpin in $\mathrm{GnRH}$ activation or inhibition.

๑) 2014 S. Karger AG, Basel

\section{Introduction}

Gonadotropin-releasing hormone ( $\mathrm{GnRH})$ neurons are the major regulators of reproductive function, and they are modulated by sex steroid feedback, metabolic status, stress and various other factors [1-4]. In turn, the neuropeptide, kisspeptin, encoded by the Kiss1 gene, is the primary upstream regulator of $\mathrm{GnRH}$ neurons through actions on $\mathrm{G}_{\mathrm{q}}$-coupled Kiss1R receptors on the cell membrane [5-7]. Mutations of the Kiss1 gene or Kiss $1 \mathrm{R}$ result in failure to reach puberty and in infertility

\section{KARGER}

E-Mail karger@karger.com

www.karger.com/nen (c) 2014 S. Karger AG, Basel

0028-3835/14/0994-0190\$39.50/0
M. Susan Smith

ONPRC, Oregon Health \& Sciences University

505 NW 185th Avenue

Beaverton, OR 97006 (USA)

E-Mail smithsu@ohsu.edu 
in humans and in some, but not all, rodent models [6-10]. Kisspeptin plays a major regulatory role of $\mathrm{GnRH}$, in both pulsatile and surge modes of secretion [11-14], and antagonism of kisspeptin's actions in adult animals results in a suppression of pulsatile LH secretion and the ovulatory LH surge [15-17]. Together these data suggest that the kisspeptin system plays a critical role in regulating $\mathrm{GnRH}$ and reproductive function.

The emerging view of kisspeptin signaling in the rodent is that it is responsible for the two modes of GnRH secretion: the arcuate nucleus (ARH) kisspeptin population regulates steroid-negative feedback and basal pulsatile $\mathrm{GnRH} / \mathrm{LH}$ release through actions at $\mathrm{GnRH}$ terminals, whereas the anteroventral periventricular (AVPV) kisspeptin population drives the estrogen-induced ovulatory $\mathrm{GnRH}$ surge through direct actions at the GnRH cell body $[1,18,19]$. Although it is widely assumed, based on mutations in kisspeptin and Kiss1R [6-9], that kisspeptin acts to sustain basal GnRH neuronal activity, there have been no studies to investigate whether endogenous basal kisspeptin tone plays a direct role in basal spontaneous GnRH neuronal excitability. If such an action of kisspeptin could be demonstrated, endogenous kisspeptin tone could play a critical role in determining GnRH excitability or inhibition during states of negative energy balance when kisspeptin and GnRH are inhibited $[1,11,20]$.

In addition to the essential role of kisspeptin in the regulation of $\mathrm{GnRH}$, many other neuropeptides have been shown to have direct effects on GnRH cells through expression of specific receptors, such as those for the majority of the neuropeptide systems regulating appetite [11, 21]. For example, neuropeptide Y (NPY) has direct inhibitory effects on GnRH [22], whereas cocaine- and amphetamine-regulated transcript (CART) has direct excitatory effects on GnRH activity [23]. In addition, the activity of these appetite-regulating neuropeptides changes greatly during states of negative energy balance where NPY activity is greatly increased [11] and CART activity is decreased [23]. Therefore, it is of interest to examine the possible interactions between kisspeptin and neuropeptides, such as NPY and CART, on GnRH neurons.

In the present study we utilized a transgenic GnRHGFP expressing rat and electrophysiological techniques to: (1) characterize the effects of a kisspeptin agonist and antagonist on GnRH activity in the rat, (2) examine the role of endogenous kisspeptin tone in spontaneous GnRH activity in female and male rats, and (3) determine if there is an interaction between endogenous kisspeptin tone and the direct actions of NPY or CART on GnRH neurons.

Basal GnRH Activity Requires Kisspeptin Tone

\section{Materials and Methods}

\section{Animals}

All animal experiments were performed in accordance with the National Institutes of Health guidelines for care and use of laboratory animals and approved by the Oregon Health \& Sciences University Institutional Animal Care and Use Committee. Adult transgenic rats (Wistar) expressing the enhanced green fluorescent protein (EGFP) under the control of the GnRH promoter were used in these studies (for details on the rats, see Xu et al. [22]). Animals were housed under standard laboratory conditions with free access to food and water. Adult female rats were ovariectomized and subcutaneously implanted with silastic implants ( $1 \mathrm{~cm} / 100 \mathrm{~g}$ body weight) containing $30 \mu \mathrm{g} / \mathrm{ml}$ estradiol in oil. These capsules create low diestrous levels of serum estradiol (5-15 $\mathrm{pg} / \mathrm{ml}[20,24])$ and provide uniform estradiol exposure to mimic basal GnRH/LH secretion, thus excluding any possible positive feedback effects of estradiol that could influence the results. Studies were also conducted on intact adult males, in which there would be basal GnRH/LH secretion.

\section{Brain Slice Preparation}

Rats were anesthetized and transcardially perfused with icecold oxygenated $\left(95 \% \mathrm{O}_{2} / 5 \% \mathrm{CO}_{2}\right)$ cutting solution (composed of (in mM) 208 sucrose, $2 \mathrm{KCl}, 1 \mathrm{MgCl}_{2}, 1.25 \mathrm{NaH}_{2} \mathrm{PO}_{4}, 26$ $\mathrm{NaHCO}_{3}, 2 \mathrm{MgSO}_{4}, 1 \mathrm{CaCl}_{2}, 10 \mathrm{HEPES}$ and 10 glucose, adjusted to $\mathrm{pH} 7.4$ with $\mathrm{NaOH}$ and continuously aerated). Brains were quickly dissected and 350- $\mu \mathrm{m}$ coronal slices through the preoptic area of the hypothalamus were cut using a vibratome. Hypothalamic slices were incubated at $34^{\circ} \mathrm{C}$ for $10 \mathrm{~min}$ in warm oxygenated artificial cerebrospinal fluid (aCSF) and then stored at room temperature until used for recording. All experiments were performed at room temperature and completed within 4-5 $\mathrm{h}$ of obtaining the brain slice to ensure cell viability. A single brain slice was transferred to the recording chamber and constantly perfused with aCSF at the rate of 2-3 $\mathrm{ml} / \mathrm{min}$. aCSF consisted of (in mM) $124 \mathrm{NaCl}, 5 \mathrm{KCl}, 2 \mathrm{MgCl}_{2}, 2.6 \mathrm{NaH}_{2} \mathrm{PO}_{4}, 26$ $\mathrm{NaHCO}_{3}, 2 \mathrm{MgSO}_{4}, 2 \mathrm{CaCl}_{2}, 10 \mathrm{HEPES}$ and 10 glucose, adjusted to $\mathrm{pH} 7.4$ with $\mathrm{NaOH}$.

\section{Electrophysiology}

Extracellular loose-patch and whole-cell patch-clamp recordings were made from the soma of EGFP-GnRH neurons. Neurons were identified using a Carl Zeiss Axioskop 2 FS (Jena, Germany) fitted with epifluorescence and infrared-differential contrast video upright microscopy. Patch pipettes were pulled from borosilicate glass capillaries with inner filaments (World Precision Instruments, Sarasota, Fla., USA) using a pp-830 electrode puller (Narishige Scientific Instrument Laboratory, Tokyo, Japan) and had resistances of 2-4 M $\Omega$ when filled with internal pipette solution (in mM): $128 \mathrm{~K}$ gluconate, $2 \mathrm{KCl}, 1 \mathrm{MgCl}_{2}, 2 \mathrm{MgATP}, 0.25 \mathrm{NaGTP}$, 11 EGTA and 10 HEPES, adjusted to $\mathrm{pH} 7.4$ with $\mathrm{NaOH}$. Electrophysiological experiments were performed using an Axopatch 200B amplifier, and signals were digitized with Digidata 1322A (Molecular Devices, Sunnyvale, Calif., USA) interfaced to a Dell computer. Data was collected using pCLAMP10 software (Molecular Devices) at a sample frequency of $20 \mathrm{kHz}$, with low-pass filtering at $2 \mathrm{kHz}$.

$\mathrm{GnRH}$ neurons were recorded from slices representing the rostral to caudal extent of $\mathrm{GnRH}$ neuronal expression. GnRH 
neurons chosen for recording had intact morphology and were within $50 \mu \mathrm{m}$ from the slice surface. Adequate whole-cell access $(\mathrm{Ra}<20 \mathrm{M} \Omega)$ and membrane resistance $(>500 \mathrm{M} \Omega$ ) were verified at the beginning and at the end of recording and were electronically compensated. Resistance was monitored throughout the recording and neurons with more than a $20 \%$ change in series resistance were rejected. Extracellular loose-patch recording was used to determine the basal spontaneous GnRH neuronal activity in hypothalamic slices from female and male rats. The effects of activation and inhibition of $\mathrm{GnRH}$ neurons were determined by analysis of spontaneous action potential firing in loose-patch recordings under voltage-clamp conditions. Drug effects on membrane potential were measured under whole-cell current-clamp conditions in the presence of TTX $(1 \mu \mathrm{M}$, tetrodotoxin citrate; Tocris Bioscience, Bristol, UK) to block activation of sodium channels. The $\mathrm{EC}_{50}$ for the kisspeptin agonist (Kp-10, Mouse KiSS-1 (110-119)- $\mathrm{NH}_{2}$; Phoenix Pharmaceuticals, Belmont, Calif., USA) and of the effective concentration of the kisspeptin antagonist, Peptide 347, were determined using hypothalamic slices from female rats and measuring changes in the membrane potential under whole-cell current-clamp conditions in the presence of TTX. The effects of the NPY Y5 receptor (Y5R) antagonist (300 $\mathrm{nM}$ ) or CART (30 nM) on GnRH neurons were also determined by similar analysis of spontaneous action potential firing and membrane potential change. The concentrations of the Y5 antagonist and CART are based on previous studies from our group $[22,23]$.

To further establish the specificity of Peptide 347, current-voltage $(\mathrm{I}-\mathrm{V})$ relationships were generated under no presynaptic block conditions to demonstrate that the kisspeptin-induced current was inhibited by Peptide 347. We used a maximum concentration of kisspeptin (100 nM) to induce consistent and quick depolarization in all cells. For similar reasons we also used a high concentration of Peptide 347 ( $30 \mathrm{nM})$. Cells were observed under current clamp for the effects of kisspeptin and Peptide 347 and allowed to reach plateau before I-V plots were constructed. Kisspeptin-induced currents were measured at a holding potential of $-55 \mathrm{mV}$. Since the membrane potential varied from -51 to $-66 \mathrm{mV}$ in the GnRH neurons examined in this study, $-55 \mathrm{mV}$ was chosen as it was closer to the more depolarized end of the range. Steady-state $\mathrm{I}-\mathrm{V}$ plots were constructed with step command potentials from -30 to $-120 \mathrm{mV}$ with steps of $10 \mathrm{mV}$ and durations of $1 \mathrm{~s}$. A similar protocol was followed to identify the nature of current induced by the Y 5 antagonist under voltage clamp. All membrane potentials were corrected for liquid junction potential by $-10 \mathrm{mV}$ for final analysis.

The drugs used in the preparation of solutions were from Sigma-Aldrich (St. Louis, Mo., USA) unless otherwise noted. All drug stocks were diluted in aCSF and delivered into the perfusion solution. The ion channel blockers/activators used were CART (55102, Rat) (American Peptide Co., Sunnyvale, Calif., USA) and Y5 antagonist, L152,804, Tocris Bioscience, UK.

\section{Data Analysis and Statistics}

Electrophysiological recordings were analyzed with Clampfit-10 software (Molecular Devices). For event analysis of individual spontaneous firing in loose-patch and action potential firing under current-clamp conditions, Mini Analysis software (Synaptosoft, Inc., Fort Lee, N.J., USA) was used. For firing analysis, the control period was the 3-min interval before drug application, and the drug effect was analyzed during a 3-min interval, starting 5 min after drug treatment. To calculate the change in frequency, events were divided by bin size (time) before and after treatment. Paired $t$ test was used to compare spontaneous firing and action potential firing percentage of GnRH neurons before and after drug treatment, $\mathrm{p}=0.05$ for significance. For membrane potential analysis, the same time intervals pre- and post-drug were used as described above for firing analysis. Statistical evaluation of mean differences in membrane potential after different treatments was performed by one-way ANOVA, with a significance at $p=0.05$. GraphPad Prism 5 software (GraphPad Software, La Jolla, Calif., USA) was used for these analyses. The $\mathrm{EC}_{50}$ for $\mathrm{Kp}-10$ and the ED for Peptide 347 were calculated from the logistic equation derived from the mean data points at each concentration. All data are expressed as mean \pm SEM

\section{Results}

Kisspeptin Depolarizes GnRH Neurons in the Rat in a Concentration-Dependent Manner

Kisspeptin has been shown to have a very prolonged postsynaptic depolarizing effect on $\mathrm{GnRH}$ neurons in a concentration-dependent manner in mice [25-27]. Here we demonstrate a similar response exists in our experimental model of GnRH-GFP female rats in which membrane potentials were measured under whole-cell current-clamp conditions and in the presence of TTX (1.0 $\mu \mathrm{M})$. The mean resting membrane potential of $\mathrm{GnRH}$ neurons was $-60.2 \pm 1.3 \mathrm{mV}(\mathrm{n}=28$ cells from 16 animals). The kisspeptin agonist, Kp-10, induced a very prolonged, concentration-dependent depolarization of GnRH neurons that persisted long after washout of the agonist (fig. 1a). Approximately $90 \%$ of cells responded to Kp-10 (fig. 1a, b). The $\mathrm{EC}_{50}$ for the Kp-10-induced depolarization was $3.32 \pm 0.02 \mathrm{nM}$ (fig. $1 \mathrm{~b}, \mathrm{n}=6-12$ cells from 3-5 animals for each concentration). The maximum depolarization evoked by $100 \mathrm{nM} \mathrm{Kp}-10$ was $20.2 \pm 1.2$ $\mathrm{mV}$. We chose to use a submaximal dose of $10 \mathrm{nM} \mathrm{Kp}-10$ in subsequent studies.

\section{Endogenous Basal Kisspeptin Tone in Female Rats}

Based on mutations in kisspeptin and Kiss1R [6-9], it has been widely assumed that kisspeptin acts to sustain basal GnRH neuronal activity, although there is no direct evidence for this role of kisspeptin. To address this question, we utilized a novel kisspeptin antagonist, Peptide 347 , to demonstrate the endogenous kisspeptin tone. The kisspeptin antagonist, Peptide 347, was derived from Peptide 234, a peptide whose structure has been published [15]. Synthesis was done by conventional solid phase and HPLC purification to yield $>80 \%$ purity, creat- 
Fig. 1. Kisspeptin (Kp-10) depolarizes $\mathrm{GnRH}$ neurons from female rats in a concentration-dependent manner. a Representative current-clamp recording in the presence of TTX showing depolarization by $10 \mathrm{nM} \mathrm{Kp}-10$. Resting membrane potential was $-62 \mathrm{mV}$. b Dose-response curve for the kisspeptin-induced depolarization. The $\mathrm{EC}_{50}$ for the kisspeptin-induced depolarization was $3.32 \pm 0.02 \mathrm{nM}(\mathrm{n}=6-12$ cells from 3-5 animals for each concentration; 1, 3, 10 and $100 \mathrm{nM})$. Data are presented as mean \pm SEM. The $\mathrm{EC}_{50}$ for Kp-10 was calculated from the logistic equation derived from the mean data points at each concentration.

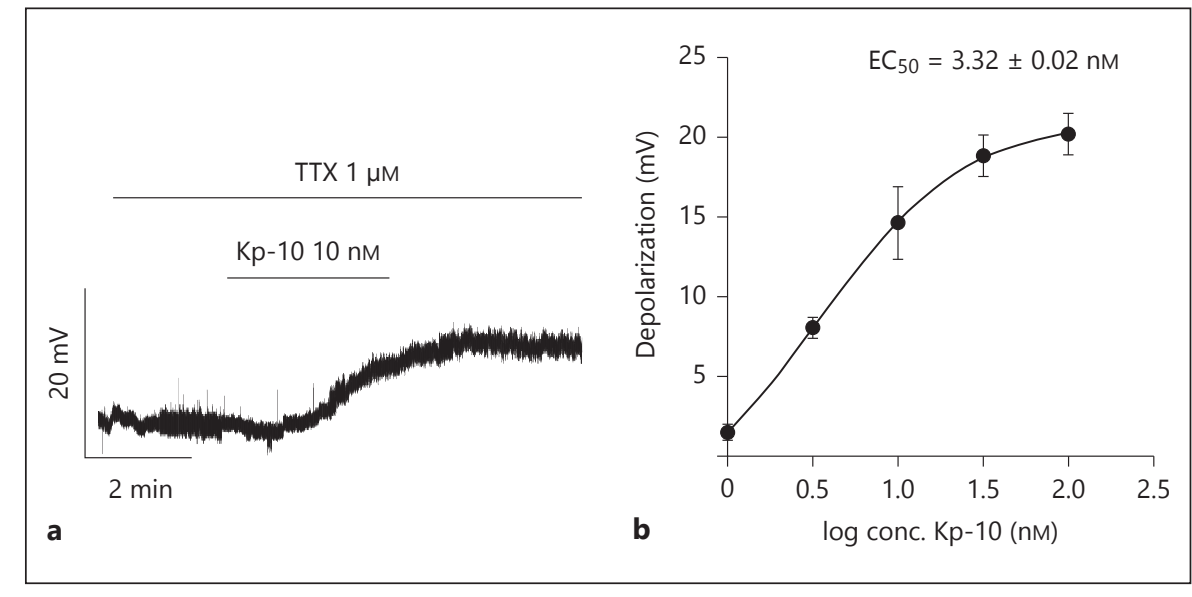

ing an antagonist with increased stability and longer duration of action. The specificity of Peptide 347 was first examined in vitro using $\mathrm{CHO}$ cells transfected with the human Kiss1R (see Supplemental Material for details). The $\mathrm{K}_{\mathrm{d}}$ (dissociation constant) for Peptide 347 was 1.0 nM, whereas for Peptide 234 and Kp-10 was 2.7 nM [15]. Also, the $\mathrm{ED}_{50}$ for Peptide 347 inhibition of $10 \mathrm{nM} \mathrm{Kp}-10$ stimulation of inositol phosphate in $\mathrm{CHO}$ cells was 1.91 nM (online suppl. fig. 1; for all online suppl. material, see www.karger.com/doi/10.1159/000365419, with methodological details), compared to $7 \mathrm{nM}$ for Peptide 234 [15]. Taken together, these data suggest that Peptide 347 is a specific, high-affinity antagonist to kisspeptin. Additional support for the specificity of the peptides derived from Peptide 234 comes from use of another similarly derived kisspeptin antagonist, Peptide 318, which has recently been reported to inhibit GnRH neuronal firing in response to AVPV-stimulated kisspeptin release [28].

To assess the role of endogenous kisspeptin tone, extracellular loose-patch recordings were made from spontaneously active $\mathrm{GnRH}$ neurons in slices from female rats. Peptide 347 (10 nM, a submaximal dose, see fig. 4) suppressed spontaneous firing events from $>30$ to $1 /$ min by 10-15 min after exposure (fig. 2a, b). It should be noted that there was a 5-to 10-min delay before the effects of the antagonist were observed, and its effects persisted after drug wash off. The average firing frequency after Peptide 347 exposure was significantly suppressed (fig. 2c: before $7.0 \pm 3.3 \mathrm{~Hz}$, after $1.1 \pm 0.3 \mathrm{~Hz}$; $=8$ cells from 5 animals; $\mathrm{p}<0.005)$. Subsequent recordings used the current-clamp configuration and demonstrated spontaneous action potential events, followed by an almost complete cessation of firing by 7-10 min after addition of Peptide 347 (fig. 2d, e). Subsequent addition of Kp-10

Basal GnRH Activity Requires Kisspeptin Tone stimulated the cell, indicating its continued viability. Overall, the action potential frequency after Peptide 347 exposure was significantly decreased (fig. 2f: before $2.8 \pm$ $0.9 \mathrm{~Hz}$, after, $0.36 \pm 0.1 \mathrm{~Hz} ; \mathrm{n}=10$ cells from 5 animals; $\mathrm{p}<0.05$ ), demonstrating that endogenous kisspeptin tone is a critical component of basal GnRH activity.

\section{Basal Endogenous Kisspeptin Tone in Male Rats}

It has been shown that kisspeptin modulates GnRH neuronal secretion in male as well as female rodents [5, 29]. GnRH neurons in the male express Kiss1R [5, 26, 30], as in the female [31], although kisspeptin fiber contacts on GnRH neurons are 3- to 4-fold less in the male than female [32]. Furthermore, kisspeptin has been shown to activate about $90 \% \mathrm{GnRH}$ neurons in the adult male mouse [26]. Therefore, we assessed whether kisspeptin was necessary to sustain basal GnRH neuronal activity in the male, as was demonstrated for the female. Extracellular loose-cell recordings were made of spontaneously active GnRH neurons in slices from intact male rats. $10 \mathrm{nM}$ Peptide 347 suppressed spontaneous firing events from $>50$ to close to $10 / \mathrm{min}$ after exposure (fig. 3a, b), and the overall average firing frequency was significantly suppressed (fig. 3c: before $7.4 \pm 2.5 \mathrm{~Hz}$, after $2.1 \pm$ $0.5 \mathrm{~Hz} ; \mathrm{n}=5$ cells from 3 animals; $\mathrm{p}<0.05$ ). Using the current-clamp configuration, spontaneous action potential events were suppressed from 60 to $13 / \mathrm{min}$ after application of Peptide 347 (fig. 3d, e), and there was a significant decrease in the average action potential frequency (fig. 3f: before $2.0 \pm 0.5 \mathrm{~Hz}$, after $0.75 \pm 0.3 \mathrm{~Hz} ; \mathrm{n}=6$ cells from 4 animals; $p<0.05$ ). These results demonstrate that endogenous kisspeptin tone is also present in male rats and plays an important role in spontaneous $\mathrm{GnRH}$ activity. 

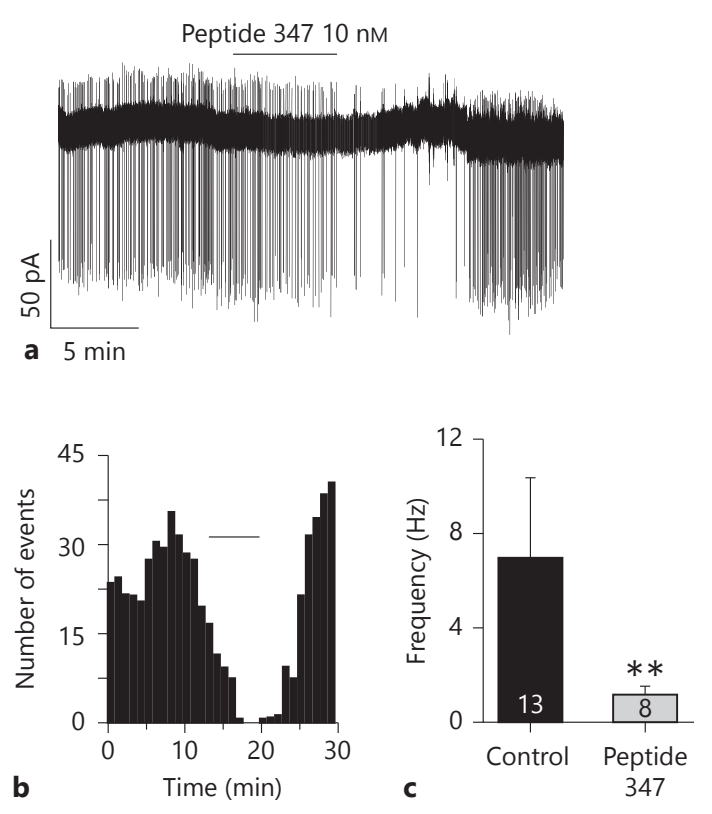

Fig. 2. Endogenous kisspeptin tone is a major component of spontaneous GnRH activity in female rats. a Representative loose cellattached recording before and after Peptide 347 exposure. Peptide 347 inhibits spontaneous neuron firing. b Histogram showing number of events/minute for the recording in panel $\mathbf{a}$. The horizontal bar indicates the duration of Peptide 347 administration. c Bar graph showing analysis of mean action potential firing frequency of loose-patch recordings of neurons before and after Peptide 347 exposure ( $n=8$ cells from 5 animals, $\left.{ }^{* *} \mathrm{p}<0.005\right)$. For firing analysis, the control period was the 3 -min interval before Peptide 347 application and the drug effect was analyzed during a
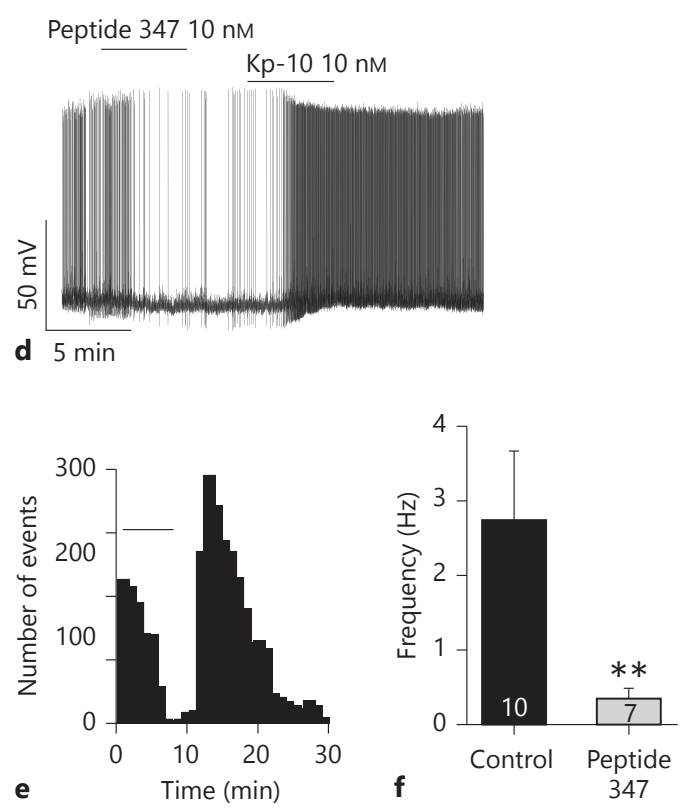

3-min interval, starting 5 min after Peptide 347 treatment. d Example of current-clamp recording demonstrating inhibition of spontaneous action potential firing of GnRH neurons by Peptide 347. Resting membrane potential was $-63 \mathrm{mV}$. The effect was reversible with wash off and application of $\mathrm{Kp}-10$. e Histogram showing number of action potential events/minute for the recording in panel $\mathbf{d}$. The horizontal bar indicates the duration of Peptide 347 administration. $\mathbf{f}$ Bar graph showing analysis of mean action potential firing frequency of current-clamp recordings of neurons, before and after Peptide 347 exposure ( $\mathrm{n}=10$ cells from 5 animals, $\left.{ }^{* *} \mathrm{p}<0.005\right)$. See panel $\mathbf{c}$ for time intervals for firing analysis.

\section{Kisspeptin Antagonist, Peptide 347, Acts Directly on GnRH Neurons to Suppress Kisspeptin-Induced Depolarization in a Concentration-Dependent Manner}

To further elucidate the actions of Peptide 347, GnRH neurons in hypothalamic slices from female rats were studied in the presence of TTX to determine the direct, postsynaptic, concentration-dependent effects of the antagonist on the GnRH cell. Application of Peptide 347 produced a small but significant hyperpolarization of the membrane potential (fig. 4a), demonstrating direct actions on the GnRH cell and providing additional support for the presence of an endogenous kisspeptin tone. The concentration-dependent inhibitory effects of Peptide 347 were measured against the constant stimulus of $10 \mathrm{nM}$ $\mathrm{Kp}-10$, a submaximal dose that causes a depolarization of $14.6 \pm 2.3 \mathrm{mV}$ (see fig. 1b). Following application of TTX and inhibition of spontaneous action potential firing, ap- plication of Peptide 347 prior to application of $10 \mathrm{nM} \mathrm{Kp}$ 10 suppressed the $\mathrm{Kp}$-10-induced depolarization to $4.5 \pm$ $1.3(1 \mathrm{nM}), 3.32 \pm 0.4(3 \mathrm{nM}), 1.47 \pm 0.12(10 \mathrm{nM})$ and $0.27 \pm 0.15$ (30 nM), respectively (fig. $4 b, c)$. The effective concentration of Peptide 347 against the $10 \mathrm{nM} \mathrm{Kp}-10$ stimuli was $5.46 \pm 0.15 \mathrm{nM}$ (fig. $4 \mathrm{c}$ ). Peptide 347 at $10 \mathrm{nM}$ (submaximal dose), and higher concentrations (up to $1 \mu \mathrm{M}$ ) produced consistent inhibitory effects and no agonist effects were observed.

\section{Peptide 347 Reverses the Kisspeptin-Induced Current in GnRH Neurons from Female Rats}

To further explore the specificity of Peptide 347 antagonistic effects, I-V curves were generated to determine the ionic nature of the inward currents induced by kisspeptin and their reversal by Peptide 347. A maximum concentration of $100 \mathrm{nM} \mathrm{Kp}-10$ was used to evoke a fast and maximum response. I- $\mathrm{V}$ relationships were obtained 

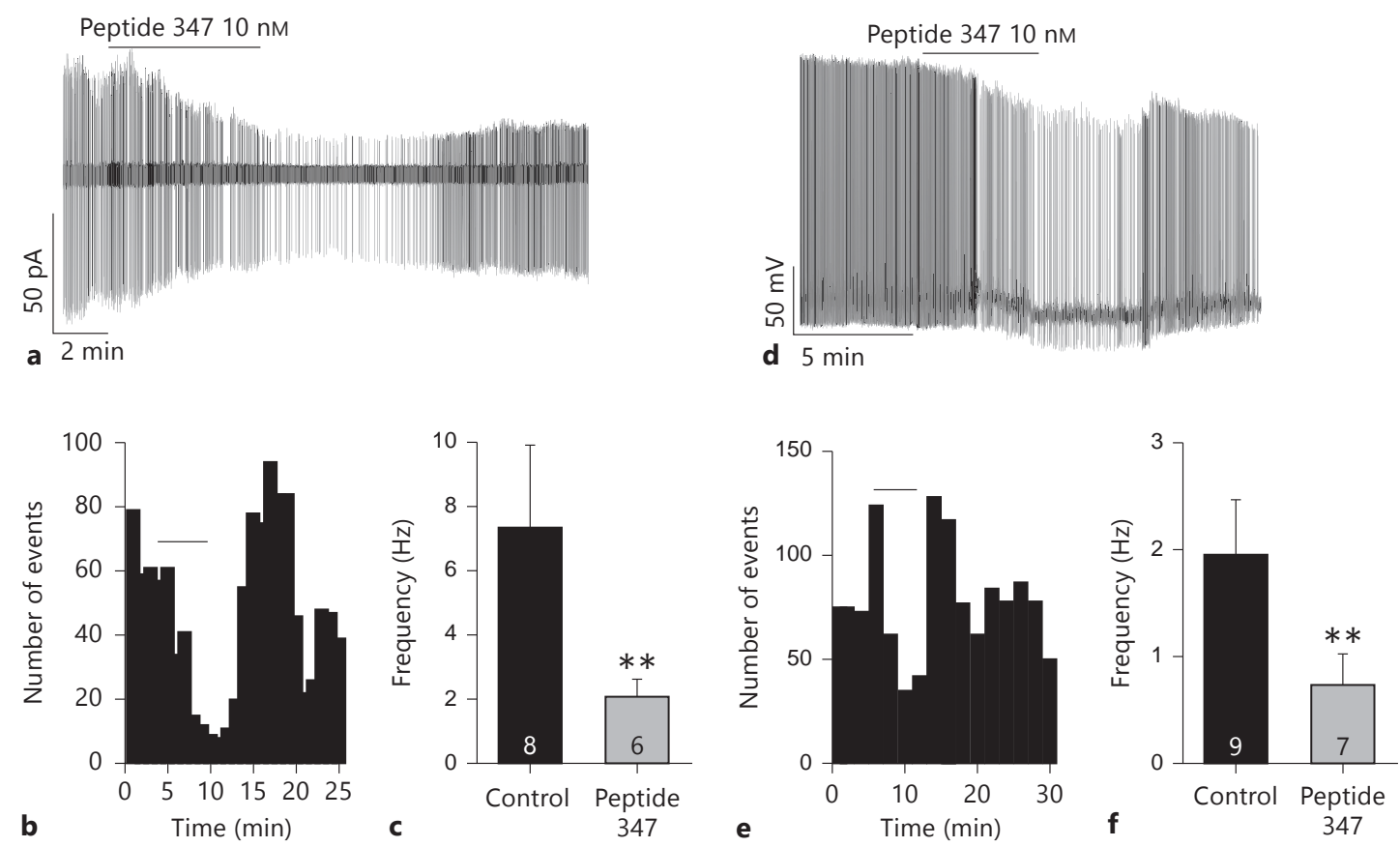

Fig. 3. Kisspeptin tone contributes to spontaneous $\mathrm{GnRH}$ activity in male rats. a Representative loose cell-attached recording before and after Peptide 347 exposure. Peptide 347 greatly reduces spontaneous neuron firing. b Histogram showing number of events/ minute for the recording in panel $\mathbf{a}$. The horizontal bar indicates the duration of Peptide 347 administration. c Bar graph showing analysis of mean action potential firing frequency of loose-patch recordings of neurons before and after Peptide 347 exposure $(\mathrm{n}=$ 5 cells from 3 animals, $\left.{ }^{* *} \mathrm{p}<0.005\right)$. Time intervals for control and Peptide 347 firing analysis are described in figure 2c. $\mathbf{d}$ Example of

current-clamp recording demonstrating suppression of spontaneous action potential firing and hyperpolarization of GnRH neurons by Peptide 347. Resting membrane potential was $-61.3 \mathrm{mV}$. e Histogram showing number of action potential events/minute for the recording in panel $\mathbf{d}$. The horizontal bar indicates the duration of Peptide 347 administration. $\mathbf{f}$ Bar graph showing analysis of mean action potential firing frequency of current-clamp recordings of neurons before and after Peptide 347 exposure $(n=6$ cells from 4 animals, $\left.{ }^{* *} \mathrm{p}<0.005\right)$. Time intervals for control and Peptide 347 firing analysis are described in figure $2 \mathrm{c}$.

immediately before Kp-10 application, after Kp-10-induced depolarization reached steady state, and after the cell reached a hyperpolarized plateau following application of $30 \mathrm{~nm}$ Peptide 347 (see representative tracings in fig. 5a). The recording in figure $5 \mathrm{~b}$ shows the kisspeptininduced current reversed at $-110 \mathrm{mV}$ (compared to control). In $65 \%$ of the cells ( 8 out of 12 cells from 5 animals), the kisspeptin-induced current was reversed between -100 and $-110 \mathrm{mV}$ after Peptide 347 exposure (fig. 5b). In the other $35 \%$ of the cells ( 4 cells), there was no apparent current reversal. Application of $30 \mathrm{nM}$ Peptide 347 alone induced hyperpolarization (6 out of 8 cells from 4 animals) and the currents reversed between -100 and $-105 \mathrm{mV}$ (fig. 5c, representative recording). The similarity in reversal potentials between Kp-10 and Peptide 347 is consistent with Peptide 347 acting at the Kiss1R.

\section{Depolarization of GnRH Neurons by Antagonizing the Y5R Requires Endogenous Kisspeptin Excitatory Tone}

Previous work from our laboratory demonstrated that the NPY Y5R postsynaptically inhibits GnRH neuronal firing in female rats, and blocking the Y5R can activate GnRH neurons, demonstrating the presence of an endogenous inhibitory NPY tone $[11,22]$. However, whether endogenous kisspeptin tone is required for other neuropeptides, such as NPY, to have these effects has not been demonstrated. The possible interaction between Y5R and Kiss $1 \mathrm{R}$ at the GnRH cell body is of physiological interest, since GnRH neurons are subjected to both endogenous excitatory kisspeptin (see above) and inhibitory NPY tone [22]. Thus, changes in the relative tone of either factor could alter basal GnRH activity. 


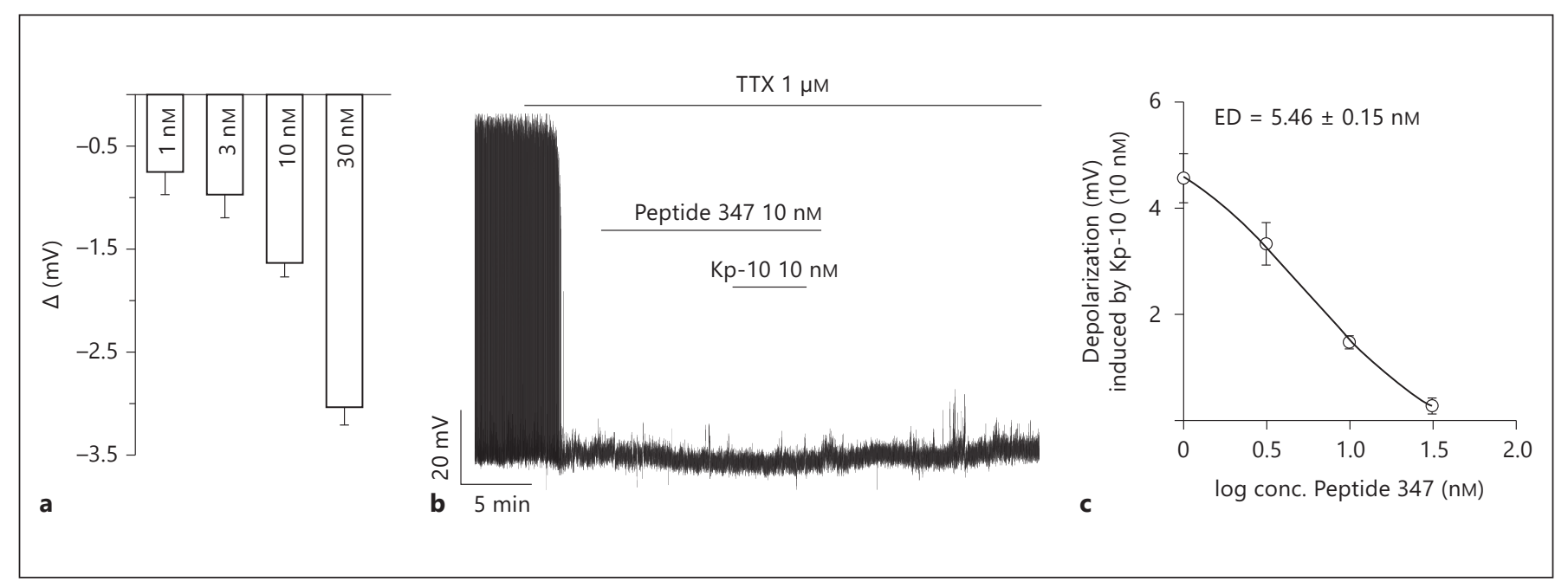

Fig. 4. Kisspeptin antagonist, Peptide 347, inhibits Kp-10-induced depolarization of GnRH neurons from female rats in a concentration-dependent manner. a Bar graph demonstrating average hyperpolarization of $\mathrm{GnRH}$ neurons after increasing concentrations of Peptide 347 (under TTX) ( $p<0.0001$ ). b Example of current-clamp recording in the presence of TTX showing that Kp-10-induced depolarization is inhibited postsynaptically by Peptide 347 . The resting membrane potential was -61.2 $\mathrm{mV}$. c Concentration of Peptide 347 (log inhibitor) versus response curve for the inhibition by Peptide 347 of Kp-10 (10 nM) induced depolarization (effective concentration $5.46 \pm 0.15 \mathrm{nM}$ ). The effective concentration for Peptide 347 was calculated from

Whole-cell current-clamp recordings of GnRH neurons from slices of female rats were performed before and after addition of the specific Y5R antagonist (300 nM $\mathrm{L} 152,804)$ in the presence of TTX to demonstrate the postsynaptic nature of the Y5R on GnRH neurons. Approximately $75 \%$ of GnRH neurons exhibited a prolonged depolarization in response to the application of L152,804 (fig. $6 \mathrm{a} ; \mathrm{n}=20$ cells from 12 animals), demonstrating the presence of an endogenous inhibitory NPY tone, as reported previously by our group [22]. The average change in membrane potential was $8.9 \pm 2.0 \mathrm{mV}$, which was significantly different when compared to controls $(\mathrm{p}<0.05)$. The I-V plot established in response to antagonizing the Y5R (fig. 6b) showed that the L152,804-induced inward current was reversed between -80 and $-90 \mathrm{mV}(\mathrm{n}=7$ cells from 3 animals) which is close to $\mathrm{E}_{\mathrm{K}}{ }^{+}(-90 \mathrm{mV})$, suggesting that the Y5R antagonist-induced effect may result from inhibition of GIRK or Kir channels.

To demonstrate a possible interaction between inhibitory NPY and excitatory kisspeptin actions on GnRH neurons, we utilized the kisspeptin antagonist, Peptide 347. Using whole-cell current-clamp, a quiescent GnRH the logistic equation derived from the mean data points at each concentration. Data are presented as mean \pm SEM. $n=32$ cells from 21 animals, 10 nonresponding cells. Note: Because the antagonist was applied first, followed by the $10 \mathrm{nM} \mathrm{Kp}-10$, it was not possible to determine if the cell was responsiveness or nonresponsive (about $10-15 \%$ of cells) to kisspeptin. To establish that the cell was a kisspeptin-responsive cell, the cells were washed for $15 \mathrm{~min}$ to remove both antagonist and agonist and then $\mathrm{Kp}-10$ was applied again. If the cell responded to this second concentration of kisspeptin, it was deemed a responsive cell. Using this protocol, the time of recording a cell was greatly extended and the number of nonresponders was increased.

cell was depolarized and action potential firing was in-

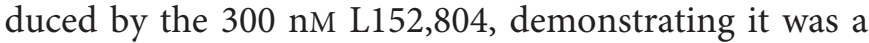
Y5R-positive GnRH cell. This firing was subsequently suppressed by $10 \mathrm{~nm}$ Peptide 347 (fig. 6c). Recording in the presence of TTX, to show the postsynaptic nature of this interaction, $300 \mathrm{nM} \mathrm{L152,804} \mathrm{depolarized} \mathrm{the} \mathrm{GnRH}$ cell (fig. $6 \mathrm{~d}$, e: $8.9 \pm 2.0 \mathrm{mV}$ ); this depolarization was significantly attenuated by subsequent application of Peptide 347 (fig. $6 \mathrm{~d}$, e: $2.42 \pm 1.06 \mathrm{mV} ; \mathrm{n}=16$ cells from 7 animals; $\mathrm{p}<0.0001$ ). These data suggest that under basal conditions, GnRH neurons can be quiescent when endogenous inhibitory NPY tone predominates over endogenous excitatory kisspeptin tone. However, after removal of the inhibitory NPY tone, endogenous kisspeptin tone is necessary for activation of GnRH neurons.

\section{CART Depolarization of GnRH Neurons Requires Endogenous Kisspeptin Tone}

To further confirm the interaction of kisspeptin with neuropeptides on the GnRH neuron, we tested the effects of CART, an excitatory neuropeptide, in the presence or absence of endogenous kisspeptin tone. We have shown 

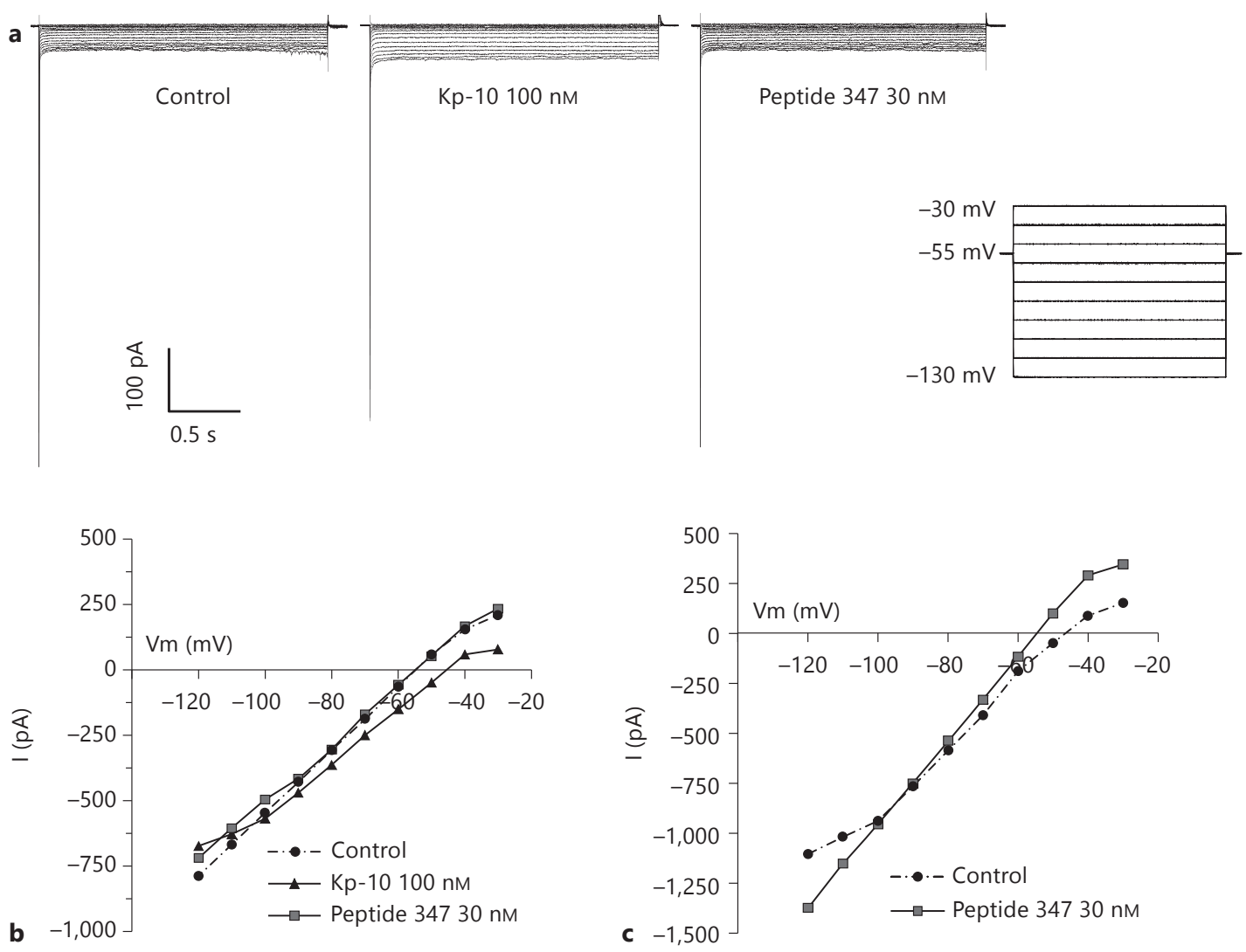

Fig. 5. Peptide 347 suppresses kisspeptin-evoked inward current in GnRH neurons from female rats. a Representative traces showing I-V relationship of sequential exposure to control, Kp-10 and Peptide 347 of the same GnRH cell from a female rat. The panel on the right shows the voltage-clamp protocol used. b Typical I-V

that CART depolarizes GnRH neurons in female rats in a concentration-dependent manner, with an $\mathrm{EC}_{50}$ of $37.4 \pm$ $1.6 \mathrm{nM}[23]$. Under whole-cell current-clamp conditions, between 60 and $70 \%$ of GnRH neurons ( 8 out of 12 cells from 5 animals) responded to $30 \mathrm{nM}$ CART with a significant membrane depolarization of $7.8 \pm 0.1 \mathrm{mV}(\mathrm{p}<$ 0.0001 ) and increased firing (fig. 7a). The effect of CART persisted long after washout, as reported previously [23], an effect that is similar to the long-lasting effects of kisspeptin. In the presence of TTX, $30 \mathrm{nM}$ CART evoked a maximum depolarization of $7.3 \pm 0.6 \mathrm{mV}$ (fig. $7 \mathrm{~b} ; \mathrm{n}=12$ cells from 6 animals), confirming our previous study [23] and suggesting that CART's stimulation of GnRH neurons may be primarily a postsynaptic effect.

Recordings using the whole-cell current-clamp configuration were made to test whether inhibition of kisspeptin tone could alter CART's stimulatory actions on curve obtained before and after Kp-10 application $\left(\mathrm{E}_{\text {rev }}=-110\right.$ $\mathrm{mV}$ ). In $65 \%$ (8 of 12 cells from 5 animals) the kisspeptin-induced current is reversed between -100 and $-110 \mathrm{mV}$ by subsequent Peptide 347 application. c I-V curve before and after Peptide 347 application. The current reversed at $-100 \mathrm{mV}$ (compared to control).

GnRH neurons. CART (30 nM) was first added to establish that the GnRH neuron was a CART-responsive cell (fig. 7c). Following application of $10 \mathrm{nM}$ Peptide 347 ( $\mathrm{n}=$ 13 cells from 6 animals), the depolarization and action potential firing induced by the second application of 30 nM CART was suppressed fig. 7c). It should be noted that earlier studies demonstrated the ability of GnRH cells to respond to a second application of CART [23]. Since most of the CART effects appear to be postsynaptic in nature (fig. 7b [23]), the effects of Peptide 347 on CART depolarization were examined in the presence of TTX. Following TTX-induced suppression of spontaneous action potentials, CART-induced depolarization was countered by Peptide 347 (fig. 7d), and the average change in membrane potential was significantly attenuated following application of Peptide 347 (fig. 7e: CART alone, $7.3 \pm 0.64$ $\mathrm{mV}, \mathrm{CART}+$ Peptide $347,0.01 \pm 0.7 \mathrm{mV} ; \mathrm{n}=12$ cells from 

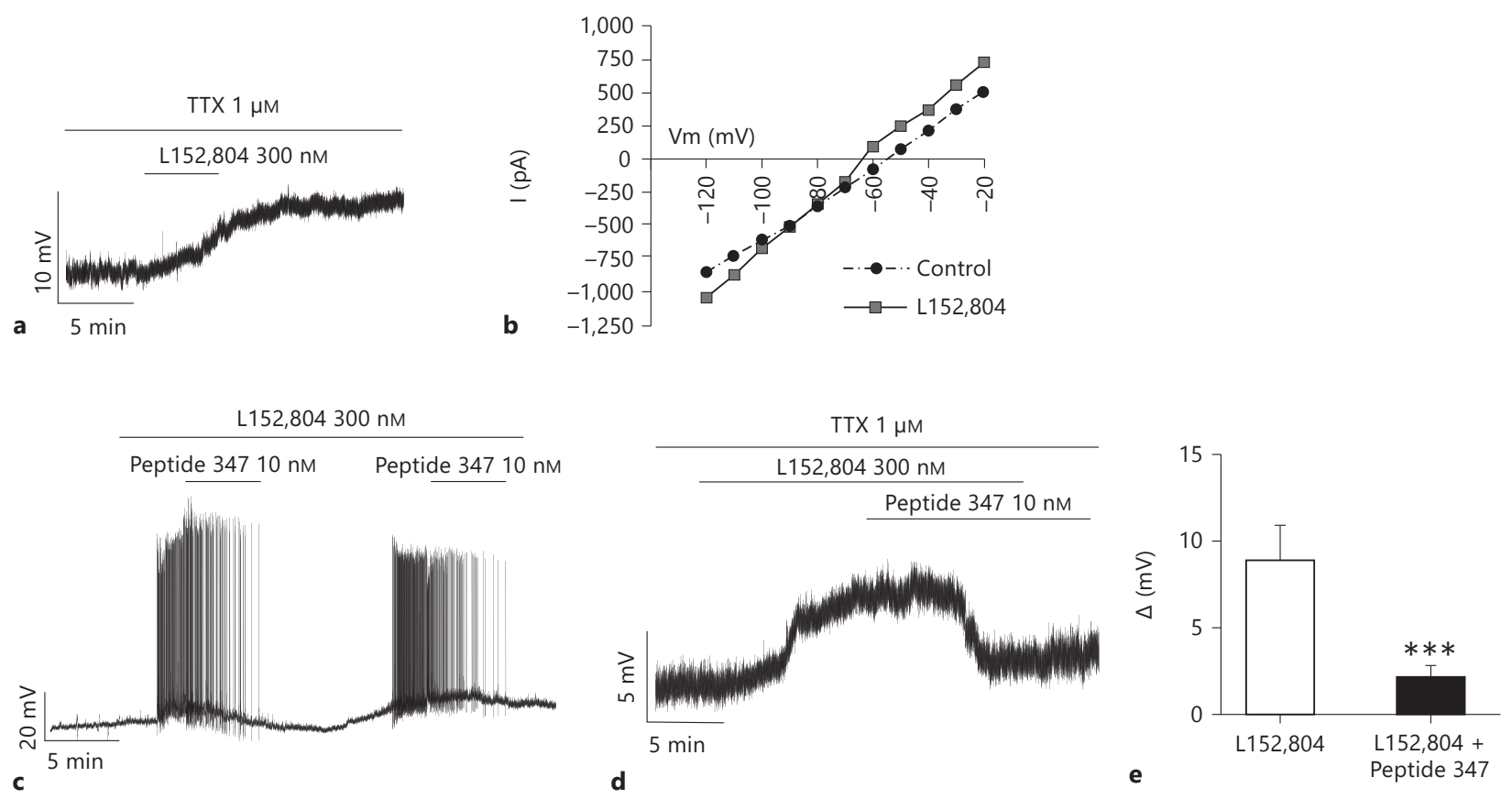

Fig. 6. Peptide 347 suppresses GnRH depolarization induced by the Y5 antagonist, L152,804. a An example of a current-clamp recording in the presence of TTX showing that the Y5 antagonist, L152,804 (300 nM), depolarizes GnRH neurons from female rats. Resting membrane potential was $-62 \mathrm{mV}$. b The mean I-V plot shows that L152,804-induced currents reversed at $\approx-85 \mathrm{mV}$ ( $\mathrm{n}=7$ cells from 3 animals). c Representative current-clamp recording of a quiescent GnRH cell in which the Y5 antagonist, L152,804, induces depolarization and spontaneous AP firing. Resting membrane potential was $-60.6 \mathrm{mV}$. Application of Peptide 347 blocks the AP firing and reverses the depolarization. d Under TTX, L152,804 induces

6 animals; $\mathrm{p}<0.0001$ ). Suppression of CART-induced depolarization by antagonizing endogenous kisspeptin tone provides further evidence that kisspeptin tone is a critical component of excitatory responses (CART or antagonizing Y5R) on GnRH neurons.

\section{Discussion}

The importance of the direct excitatory effect of kisspeptin on GnRH neurons is well documented. Here for the first time, our electrophysiology studies using hypothalamic slices provide evidence that basal endogenous kisspeptin tone appears to be essential for spontaneous $\mathrm{GnRH}$ neuronal firing in female and male rats, since antagonism of endogenous kisspeptin activity suppresses spontaneous GnRH activity. We also found that the di- depolarization with no spiking; the depolarization is largely suppressed by Peptide 347 . Resting membrane potential was $-63.3 \mathrm{mV}$. e Histogram showing analysis under TTX of depolarization induced by L152,804 alone $(8.9 \pm 2.0 \mathrm{mV})$ and in the presence of Peptide $347\left(2.17 \pm 0.6 \mathrm{mV}, \mathrm{n}=16\right.$ cells from 7 animals, $\left.{ }^{* * *} \mathrm{p}<0.0001\right)$ respectively. For analysis of the change in membrane potential, the control period was the 3-min interval before L152,804 application, and the drug effect was analyzed during a 3-min interval, starting 5 min after L152,804. When the peak depolarization occurred, Peptide 347 was added and membrane potential was analyzed for a 3-min interval starting 10 min after Peptide 347 application. rect actions of NPY and CART on GnRH neurons are greatly dependent on the presence of endogenous kisspeptin tone. Therefore, our results implicate endogenous basal kisspeptin tone as a major factor in determining the final state of excitability of GnRH neurons.

In examining the two distinct populations of kisspeptin neurons in rodents (ARH and AVPV) that modulate $\mathrm{GnRH}$ neurons, kisspeptin fiber projection studies in the female suggest that the majority of kisspeptin-immunoreactive fibers around GnRH cell bodies arise from cells in the AVPV and this population has been assumed to be responsible for the GnRH/LH surge $[1,29,33]$. AVPV kisspeptin neuronal expression is almost 25 times greater in females as compared to adult males [34, 35], and projections from the AVPV are more robustly expressed in females than in males $[32,36]$, reflecting the sexually dimorphic nature of the AVPV $[37,38]$. How- 


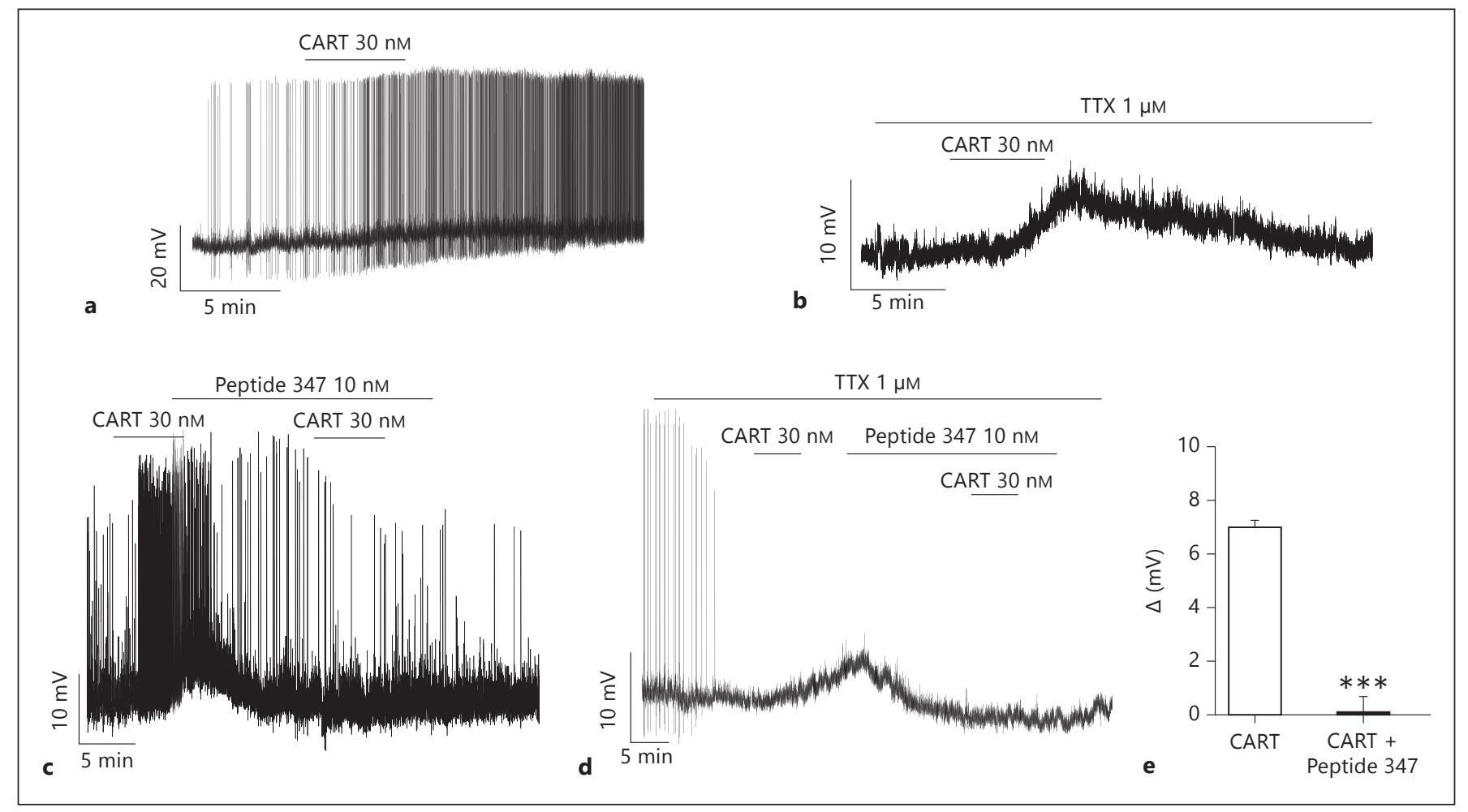

Fig. 7. Peptide 347 suppresses GnRH depolarization induced by CART. a Example of CART-induced depolarization and spontaneous firing in GnRH neurons from female rats. Resting membrane potential was $-62 \mathrm{mV}$. b Example of CART-induced depolarization, under TTX, with no spiking. Resting membrane potential was $-64 \mathrm{mV}$. c Example of Peptide 347 suppressing the CART-induced spontaneous firing and depolarization of GnRH neurons. Resting membrane potential was $-61 \mathrm{mV}$. d Under TTX,

ever, a critical role for endogenous kisspeptin tone on $\mathrm{GnRH}$ activity in the male was clearly demonstrated by these studies, reflecting the abundance of kisspeptin fibers in close apposition to GnRH cells in the male and the high level of responsiveness of GnRH neurons to kisspeptin in the male $[26,32]$. Regardless of the origin of the kisspeptin fibers, AVPV or ARH, our results expand the role of kisspeptin neuronal input to $\mathrm{GnRH}$ neurons as also providing critical endogenous basal excitatory tone that is critical for spontaneous GnRH activity and action potential firing in both female and male rats.

Our results in the rat regarding kisspeptin's actions on $\mathrm{GnRH}$ neurons are in agreement with previous findings in the mouse. Kisspeptin stimulated GnRH neurons in a concentration-dependent manner, with a similar $\mathrm{EC}_{50}$ of $3.32 \pm 0.02 \mathrm{nM}$, as shown in mice [27]. Nearly $90 \%$ of the $\mathrm{GnRH}$ cells responded to kisspeptin in our experiments; this correlates with the Kiss $1 \mathrm{R}$ receptor expression on

Basal GnRH Activity Requires Kisspeptin Tone
CART depolarizes GnRH neurons and this effect is suppressed by application of Peptide 347. Resting membrane potential was -62.5 $\mathrm{mV}$. e Histogram summarizing the depolarizing effects of CART under TTX and the suppressing effects of Peptide 347 (CART alone, $7.3 \pm 0.64 \mathrm{mV}$; CART with Peptide 347, $0.66 \pm 0.6 \mathrm{mV} ; 12$ cells from 6 animals, $\left.{ }^{* * *} \mathrm{p}<0.001\right)$. For the analysis of the change in membrane potential, see details in figure $6 \mathrm{e}$.

GnRH neurons and with c-Fos induction data [5, 39]. Kisspeptin acts through the $\mathrm{G}_{\mathrm{q} / \mathrm{s}}$-coupled Kiss $1 \mathrm{R}$ mediating GnRH activation [40], leading to sustained membrane depolarization and increased action potential firing [27]. Data from mice and guinea pigs have shown that kisspeptin-induced currents in GnRH neurons result from simultaneous inhibition of resting Kir (inwardly rectifying potassium) channels [41] and activation of the canonical transient receptor potential (TRPC) channel to yield a reversal potential $(-100$ to $-110 \mathrm{mV})$, significantly more negative than $\mathrm{E}_{\mathrm{k}}+(-90 \mathrm{mV})[27,42,43]$. We found similar I-V relationships in the rat, so it is reasonable to speculate that the kisspeptin-induced currents in GnRH neurons in the rat may also consist of activation of TRPC channels and inhibition of potassium currents as shown by Zhang et al. [27] in the mouse.

We used a novel kisspeptin antagonist Peptide 347, a longer duration, highly potent derivative of Peptide 234, 
to demonstrate the presence of endogenous kisspeptin tone acting on rat GnRH neurons. We found similar results with Peptide 318 [28], which is another longer duration derivative of Peptide 234, although it is less potent than Peptide 347. Peptide 234 has been shown to inhibit kisspeptin-induced activation of GnRH neurons in both in vitro and in vivo experiments in rodents and primates [15-17], although in one experiment, there was no effect of Peptide 234 on spontaneous GnRH activity [15]. There does not appear to be an obvious explanation for the difference in results; however, our studies are much more extensive, and Peptide 347 is a more potent antagonist because of its much lower $\mathrm{K}_{\mathrm{d}}$ and $\mathrm{ED}$. Our results from in vitro and brain slice studies provide several lines of evidence that Peptide 347 is acting as a Kiss $1 \mathrm{R}$ antagonist: (1) Peptide 347 blocked the kisseptin-induced inositol phosphate production in $\mathrm{CHO}$ cells; (2) the effects of Peptide 347 were concentration-dependent in nature, similar to kisspeptin [27]; (3) Peptide 347 reversed the kisspeptin-induced current $(-100$ to $-110 \mathrm{mV})$, and (4) the negative reversal potential of Peptide 347 alone $(-100$ to $-105 \mathrm{mV}$ ) demonstrated the similarity of the currents affected by kisspeptin and Peptide 347 [27]. Importantly, Peptide 347 suppressed neuronal firing in $80-90 \%$ of the GnRH cells in hypothalamic slices from both female and male rats, and the effects were similar in the presence or absence of TTX, suggesting that most of the antagonist's effects were postsynaptic in nature, similar to the effects of the Kp-10 agonist.

Although kisspeptin has been shown to modulate other neuropeptide systems - it depolarizes and increases firing in POMC neurons and inhibits activation of orexigenic NPY neurons $[44,45]$ - the potential interaction between kisspeptin and neuropeptides at the GnRH neuron is largely unknown but of physiological importance. We began our exploration with NPY, as previous work from our group and others has demonstrated the following: (1) the inhibitory orexigenic NPY neurons directly innervate approximately $50 \%$ of GnRH neurons [46]; (2) the majority of the NPY fibers originate from the ARH $[46,47]$; (3) the NPY Y5R are expressed on about $50 \%$ of GnRH cells in the rat [48], and (4) antagonizing the Y5R blocks the effects of endogenous inhibitory NPY tone, primarily through postsynaptic effects [22], and results in activation of the majority of $\mathrm{GnRH}$ neurons, reflecting the percentage of GnRH neurons that express the Y5R [48]. The data from this study confirm our previous findings in the rat [22]. Although recent work done in mice demonstrated a very limited effect of NPY Y5R antagonism on GnRH neurons [49], it is possible there may be substantial species differences when it comes to NPY receptor pharmacology in rats and mice. The NPY Y5R antagonist-induced current in our studies reversed at -85 $\mathrm{mV}$, suggesting that the Y5R antagonist blocked activation of Kir or GIRK channels through the $\mathrm{G}_{\mathrm{i} / \mathrm{o}}$ family of GPCRs $[50,51]$; these possibilities are currently being tested pharmacologically. Our results also showed that activation of GnRH neurons by blocking the Y5R required endogenous kisspeptin tone. It is interesting that antagonizing the $\mathrm{Y} 5 \mathrm{R}$ resulted in a prolonged activation of the GnRH cell, similar to the effects of kisspeptin. If NPY's inhibitory actions are primarily through Kir or GIRK channels, then the actions of the Y5R antagonist would block these channels and perhaps reveal the excitatory actions of endogenous kisspeptin tone [27]. In speculating about the essential nature of kisspeptin's actions that are required for activation of the GnRH cell, it is possible that activation of TRPC channels may be a requisite component of GnRH cell firing, a component that is provided by endogenous kisspeptin tone [27].

Recent work from our group has identified CART as a novel stimulator of both kisspeptin and GnRH neurons [23]. CART neurons are expressed throughout the CNS and its mRNA and peptide have been identified in various hypothalamic regions [52, 53]. Our work has shown that CART fibers are in close apposition to approximately $60 \%$ of $\mathrm{GnRH}$ neurons in the preoptic area [23]. In the present study, we found that CART induced depolarization in the majority of $\mathrm{GnRH}$ neurons, in keeping with the percentage of GnRH neurons contacted by CART fibers [23]. In addition, CART's effects were long-lasting, similar to the effects of kisspeptin [23, 25]. Furthermore, our data suggest that CART's effects may be postsynaptic in nature on GnRH cells, although additional studies employing GABA and glutamate blockers, in addition to TTX, are necessary to provide definitive proof. The CART-induced increased action potential firing was consistently blocked by Peptide 347, suggesting an interaction between CART and kisspeptin. In considering possible mechanisms for this interaction, it is difficult to speculate because CART receptors have yet to be identified. Therefore, it is not possible to know whether CART's effects are on the same or different membrane channels as those for kisspeptin. However, a similar explanation as provided for the requirement of endogenous kisspeptin tone for the excitatory effects of the Y5R could obtain here, that activation of TRPC channels by kisspeptin may be a requisite component of $\mathrm{GnRH}$ cell firing. Taken together, these findings portray the novelty and importance of endogenous kisspeptin tone for excitatory ac- 
tions of neuropeptides on GnRH neurons. Studies in progress are exploring pharmacologically whether activation of TRPC channels is an essential component in GnRH activity.

Our findings provide an important analysis of the interaction between neural circuits controlling reproduction and feeding. Under states of negative energy balance, the orexigenic effects of NPY are increased, causing an increased inhibitory effect on GnRH neurons, resulting in a higher percentage of quiescent GnRH neurons [1, 22]. In contrast, CART levels are decreased during states of negative energy balance $[23,54,55]$. In addition, it has been shown that lactation, fasting and caloric restriction lead to a reduction in kisspeptin in both ARH and AVPV $[1,20,56-58]$. Therefore, during conditions of negative energy balance, decreased kisspeptin tone, coupled with an increase in inhibitory NPY and a decrease in excitatory CART, could be major components in suppressed GnRH activity.

These studies also provided additional support for our earlier observations that there may be continued release of neuropeptides under conditions of TTX, as evidenced by the ability to demonstrate effects of the Y5R and kisspeptin antagonists (fig. 4, 6; [22]). The effects of TTX were evident by the absence of action potentials or spikes after treatment. Current dogma supports the idea that release of neuropeptides requires activated sodium channels, which are blocked under TTX. However, our data suggest that there may be continued presence of neuropeptides in the synapse and areas surrounding the GnRH neuron. Under our experimental conditions, the antagonists were effective even beyond $30 \mathrm{~min}$ of TTX exposure (data not shown), suggesting that there is a release component of neuropeptides that is not blocked by TTX. Since we observed these antagonist effects with both kisspeptin and NPY, antagonists to completely different receptors, this suggests that the phenomenon is not linked to a specific type of receptor or ligand. Support for the possibility of continued basal release of neuropeptides in the absence of activated sodium channels comes from studies of other neuropeptides in the hypothalamus, where continuous presence of oxytocin and vasopressin primes the dendrites in the supraoptic nucleus for release of vasopressin and oxytocin independent of electrical activity of the cell [59-61].

In conclusion, the current novel findings are derived from electrophysiological recordings of GnRH neurons and provide evidence supporting the widely held assumption that kisspeptin drives basal GnRH neuronal activity. Endogenous basal kisspeptin tone appears to be required for spontaneously activity in GnRH neurons, based on the results using a kisspeptin antagonist, Peptide 347, whose actions are consistent with blocking the Kiss1R. Furthermore, excitatory kisspeptin tone appears to be required for the excitatory effects of inhibition of Y5R or of CART on GnRH neurons. The requirement for kisspeptin tone may reflect the requirement for specific channel activation or inhibition that is necessary to activate GnRH neuronal firing. We also provide continuing evidence that there may be basal release of neuropeptides such as kisspeptin and NPY that is independent of the electrical activity of the cell. These studies present a possible model where endogenous kisspeptin tone could serve as the linchpin in GnRH activation or inhibition depending on the metabolic state of the animal.

\section{Acknowledgements}

The authors would like to acknowledge the NIH grants that supported this work HD014643, HD014643 (ARRA Supplement), OD011092.

\section{Disclosure Statement}

The authors declare no competing financial interests.

\section{References}

1 True C, Kirigiti M, Ciofi P, Grove KL, Smith MS: Characterisation of arcuate nucleus kisspeptin/neurokinin B neuronal projections and regulation during lactation in the rat. J Neuroendocrinol 2011;23:52-64.

2 Li XF, Kinsey-Jones JS, Cheng Y, Knox AM, Lin Y, Petrou NA, Roseweir A, Lightman SL, Milligan SR, Millar RP, O’Byrne KT: Kisspeptin signalling in the hypothalamic arcuate nucleus regulates $\mathrm{GnRH}$ pulse generator frequency in the rat. PLoS One 2009;4:e8334.
3 Grachev P, Li XF, Lin YS, Hu MH, Elsamani L, Paterson SJ, Millar RP, Lightman SL, O’Byrne KT: GPR54-dependent stimulation of luteinizing hormone secretion by neurokinin B in prepubertal rats. PLoS One 2012; 7:e44344.

4 Centeno ML, Sanchez RL, Cameron JL, Bethea CL: Hypothalamic gonadotrophin-releasing hormone expression in female monkeys with different sensitivity to stress. J Neuroendocrinol 2007;19:594-604.
5 Irwig MS, Fraley GS, Smith JT, Acohido BV Popa SM, Cunningham MJ, Gottsch ML, Clifton DK, Steiner RA: Kisspeptin activation of gonadotropin releasing hormone neurons and regulation of KiSS-1 mRNA in the male rat. Neuroendocrinology 2004;80:264-272.

6 De Roux N, Genin E, Carel JC, Matsuda F, Chaussain JL, Milgrom E: Hypogonadotropic hypogonadism due to loss of function of the KiSS1-derived peptide receptor GPR54. Proc Natl Acad Sci USA 2003;100:10972-10976. 
7 Seminara SB, Messager S, Chatzidaki EE, Thresher RR, Acierno JS Jr, Shagoury JK, BoAbbas Y, Kuohung W, Schwinof KM, Hendrick AG, Zahn D, Dixon J, Kaiser UB, Slaugenhaupt SA, Gusella JF, O'Rahilly S, Carlton MB, Crowley WF Jr, Aparicio SA, Colledge WH: The GPR54 gene as a regulator of puberty. N Engl J Med 2003;349:1614-1627.

8 Lapatto R, Pallais JC, Zhang D, Chan YM, Mahan A, Cerrato F, Le WW, Hoffman GE, Seminara SB: Kiss1-/- mice exhibit more variable hypogonadism than Gpr54-/- mice. Endocrinology 2007;148:4927-4936.

9 D'Anglemont de Tassigny X, Fagg LA, Dixon JP, Day K, Leitch HG, Hendrick AG, Zahn D, Franceschini I, Caraty A, Carlton MB, Aparicio SA, Colledge WH: Hypogonadotropic hypogonadism in mice lacking a functional Kiss1 gene. Proc Natl Acad Sci USA 2007;104: 10714-10719.

10 Mayer C, Boehm U: Female reproductive maturation in the absence of kisspeptin/GPR54 signaling. Nat Neurosci 2011;14:704-710.

11 Smith MS, True C, Grove KL: The neuroendocrine basis of lactation-induced suppression of GnRH: Role of kisspeptin and leptin. Brain Res 2010;1364:139-152.

12 Gottsch ML, Cunningham MJ, Smith JT, Popa SM, Acohido BV, Crowley WF, Seminara S, Clifton DK, Steiner RA: A role for kisspeptins in the regulation of gonadotropin secretion in the mouse. Endocrinology 2004; 145:4073-4077.

13 Castellano JM, Roa J, Luque RM, Dieguez C, Aguilar E, Pinilla L, Tena-Sempere M: KiSS$1 /$ kisspeptins and the metabolic control of reproduction: physiologic roles and putative physiopathological implications. Peptides 2009;30:139-145.

14 Kauffman AS, Clifton DK, Steiner RA: Emerging ideas about kisspeptin-GPR54 signaling in the neuroendocrine regulation of reproduction. Trends Neurosci 2007;30:504511.

15 Roseweir AK, Kauffman AS, Smith JT, Guerriero KA, Morgan K, Pielecka-Fortuna J, Pineda R, Gottsch ML, Tena-Sempere M, Moenter SM, Terasawa E, Clarke IJ, Steiner RA, Millar RP: Discovery of potent kisspeptin antagonists delineate physiological mechanisms of gonadotropin regulation. J Neurosci 2009;29:3920-3929.

16 Guerriero KA, Keen KL, Millar RP, Terasawa E: Developmental changes in GnRH release in response to kisspeptin agonist and antagonist in female rhesus monkeys (Macaca mulatta): implication for the mechanism of puberty. Endocrinology 2012;153:825-836.

17 Grachev P, Li XF, Lin YS, Hu MH, Elsamani L, Paterson SJ, Millar RP, Lightman SL, O’Byrne KT: GPR54-dependent stimulation of luteinizing hormone secretion by neurokinin B in prepubertal rats. PLoS One 2012; 7:e44344.

18 Dungan HM, Gottsch ML, Zeng H, Gragerov A, Bergmann JE, Vassilatis DK, Clifton DK, Steiner RA: The role of kisspeptin-GPR54 sig- naling in the tonic regulation and surge release of gonadotropin-releasing hormone/luteinizing hormone. J Neurosci 2007;27: 12088-12095.

19 Uenoyama Y, Tsukamura H, Maeda KI: Kisspeptin/metastin: a key molecule controlling two modes of gonadotrophin-releasing hormone/luteinising hormone release in female rats. J Neuroendocrinol 2009;21:299-304.

20 True C, Kirigiti MA, Kievit P, Grove KL, Smith MS: Leptin is not the critical signal for kisspeptin or luteinising hormone restoration during exit from negative energy balance. J Neuroendocrinol 2011;23:1099-1112.

21 True C, Grove KL, Smith MS: Beyond leptin: emerging candidates for the integration of metabolic and reproductive function during negative energy balance. Front Endocrinol (Lausanne) 2011;2:53.

$22 \mathrm{Xu}$ J, Kirigiti MA, Cowley MA, Grove KL, Smith MS: Suppression of basal spontaneous gonadotropin-releasing hormone neuronal activity during lactation: role of inhibitory effects of neuropeptide Y. Endocrinology 2009; 150:333-340.

23 True C, Verma S, Grove KL, Smith MS: Cocaine- and amphetamine-regulated transcript is a potent stimulator of $\mathrm{GnRH}$ and kisspeptin cells and may contribute to negative energy balance-induced reproductive inhibition in females. Endocrinology 2013;154:2821-2832.

24 Goodman RL: A quantitative analysis of the physiological role of estradiol and progesterone in the control of tonic and surge secretion of luteinizing hormone in the rat. Endocrinology 1978;102:142-150.

25 Pielecka-Fortuna J, Chu Z, Moenter SM: Kisspeptin acts directly and indirectly to increase gonadotropin-releasing hormone neuron activity and its effects are modulated by estradiol. Endocrinology 2008;149:1979-1986.

26 Han SK, Gottsch ML, Lee KJ, Popa SM, Smith JT, Jakawich SK, Clifton DK, Steiner RA, Herbison AE: Activation of gonadotropin-releasing hormone neurons by kisspeptin as a neuroendocrine switch for the onset of puberty. J Neurosci 2005;25:11349-11356.

27 Zhang C, Roepke TA, Kelly MJ, Ronnekleiv OK: Kisspeptin depolarizes gonadotropin-releasing hormone neurons through activation of TRPC-like cationic channels. J Neurosci 2008;28:4423-4434.

28 Liu X, Porteous R, d'Anglemont de Tassigny X, Colledge WH, Millar R, Petersen SL, Herbison AE: Frequency-dependent recruitment of fast amino acid and slow neuropeptide neurotransmitter release controls gonadotropin-releasing hormone neuron excitability. J Neurosci 2011;31:2421-2430.

29 Clarkson J, d'Anglemont de Tassigny X, Moreno AS, Colledge WH, Herbison AE: Kisspeptin-GPR54 signaling is essential for preovulatory gonadotropin-releasing hormone neuron activation and the luteinizing hormone surge. J Neurosci 2008;28:8691-8697.

30 Poling MC, Kauffman AS: Sexually dimorphic testosterone secretion in prenatal and neonatal mice is independent of kisspeptinKiss1r and GnRH signaling. Endocrinology 2012;153:782-793.

31 Kauffman AS, Park JH, McPhie-Lalmansingh AA, Gottsch ML, Bodo C, Hohmann JG, Pavlova MN, Rohde AD, Clifton DK, Steiner RA, Rissman EF: The kisspeptin receptor GPR54 is required for sexual differentiation of the brain and behavior. J Neurosci 2007;27:88268835.

32 Clarkson J, Herbison AE: Postnatal development of kisspeptin neurons in mouse hypothalamus; sexual dimorphism and projections to gonadotropin-releasing hormone neurons. Endocrinology 2006;147:5817-5825.

33 Smith JT, Cunningham MJ, Rissman EF, Clifton DK, Steiner RA: Regulation of Kiss 1 gene expression in the brain of the female mouse. Endocrinology 2005;146:3686-3692.

34 Smith JT, Dungan HM, Stoll EA, Gottsch ML, Braun RE, Eacker SM, Clifton DK, Steiner RA: Differential regulation of KiSS-1 mRNA expression by sex steroids in the brain of the male mouse. Endocrinology 2005; 146:29762984.

35 De Croft S, Piet R, Mayer C, Mai O, Boehm U, Herbison AE: Spontaneous kisspeptin neuron firing in the adult mouse reveals marked sex and brain region differences but no support for a direct role in negative feedback. Endocrinology 2012;153:5384-5393.

36 Iijima N, Takumi K, Sawai N, Ozawa H: An immunohistochemical study on the expressional dynamics of kisspeptin neurons relevant to GnRH neurons using a newly developed anti-kisspeptin antibody. J Mol Neurosci 2011;43:146-154.

37 Kauffman AS, Gottsch ML, Roa J, Byquist AC, Crown A, Clifton DK, Hoffman GE, Steiner RA, Tena-Sempere M: Sexual differentiation of Kiss 1 gene expression in the brain of the rat. Endocrinology 2007;148:1774-1783.

38 Simerly RB: Wired for reproduction: organization and development of sexually dimorphic circuits in the mammalian forebrain. Annu Rev Neurosci 2002;25:507-536.

39 Matsui H, Takatsu Y, Kumano S, Matsumoto $\mathrm{H}$, Ohtaki T: Peripheral administration of metastin induces marked gonadotropin release and ovulation in the rat. Biochem Biophys Res Com 2004;320:383-388.

40 Messager S, Chatzidaki EE, Ma D, Hendrick AG, Zahn D, Dixon J, Thresher RR, Malinge I, Lomet D, Carlton MB, Colledge WH, Caraty A, Aparicio SA: Kisspeptin directly stimulates gonadotropin-releasing hormone release via $G$ protein-coupled receptor 54. Proc Natl Acad Sci USA 2005;102:1761-1766.

41 Logothetis DE, Zhang H: Gating of G proteinsensitive inwardly rectifying $\mathrm{K}^{+}$channels through phosphatidylinositol 4,5-bisphosphate. J Physiol 1999;520:630.

42 Qiu J, Fang Y, Bosch MA, Ronnekleiv OK, Kelly MJ: Guinea pig kisspeptin neurons are depolarized by leptin via activation of TRPC channels. Endocrinology 2011;152:15031514. 
43 Lagrange AH, Ronnekleiv OK, Kelly MJ: Estradiol-17 $\beta$ and $\mu$-opioid peptides rapidly hyperpolarize GnRH neurons: a cellular mechanism of negative feedback? Endocrinology 1995;136:2341-2344.

$44 \mathrm{Fu}$ LY, van den Pol AN: Kisspeptin directly excites anorexigenic proopiomelanocortin neurons but inhibits orexigenic neuropeptide $\mathrm{Y}$ cells by an indirect synaptic mechanism. J Neurosci 2010;30:10205-10219.

45 Backholer K, Smith JT, Rao A, Pereira A, Iqbal J, Ogawa S, Li Q, Clarke IJ: Kisspeptin cells in the ewe brain respond to leptin and communicate with neuropeptide $\mathrm{Y}$ and proopiomelanocortin cells. Endocrinology 2010;151: 2233-2243.

46 Li C, Chen P, Smith MS: Morphological evidence for direct interaction between arcuate nucleus neuropeptide Y (NPY) neurons and gonadotropin-releasing hormone neurons and the possible involvement of NPY Y1 receptors. Endocrinology 1999;140:5382-5390.

47 Turi GF, Liposits Z, Moenter SM, Fekete C, Hrabovszky E: Origin of neuropeptide Y-containing afferents to gonadotropin-releasing hormone neurons in male mice. Endocrinology 2003;144:4967-4974.

48 Campbell RE, French-Mullen JM, Cowley MA, Smith MS, Grove KL: Hypothalamic circuitry of neuropeptide $\mathrm{Y}$ regulation of neuroendocrine function and food intake via the $\mathrm{Y} 5$ receptor subtype. Neuroendocrinology 2001; 74:106-119.

49 Roa J, Herbison AE: Direct regulation of GnRH neuron excitability by arcuate nucleus POMC and NPY neuron neuropeptides in female mice. Endocrinology 2012;153:5587-5599.
50 Fu LY, Acuna-Goycolea C, van den Pol AN: Neuropeptide Y inhibits hypocretin/orexin neurons by multiple presynaptic and postsynaptic mechanisms: tonic depression of the hypothalamic arousal system. J Neurosci 2004; 24:8741-8751.

51 Sato N, Ando M, Ishikawa S, Jitsuoka M, Nagai K, Takahashi H, Sakuraba A, Tsuge H, Kitazawa H, Iwaasa H, Mashiko S, Gomori A, Moriya R, Fujino N, Ohe T, Ishihara A, Kanatani A, Fukami T: Discovery of tetrasubstituted imidazolines as potent and selective neuropeptide Y Y5 receptor antagonists: reduced human ether-a-go-go related gene potassium channel binding affinity and potent antiobesity effect. J Med Chem 2009;52:3385-3396.

52 Couceyro PR, Koylu EO, Kuhar MJ: Further studies on the anatomical distribution of CART by in situ hybridization. J Chem Neuroanat 1997;12:229-241.

53 Koylu EO, Couceyro PR, Lambert PD, Ling NC, DeSouza EB, Kuhar MJ: Immunohistochemical localization of novel CART peptides in rat hypothalamus, pituitary and adrenal gland. J Neuroendocrinol 1997;9:823-833.

54 Van Vugt DA, Lujan ME, Froats M, Krzemien A, Couceyro PR, Reid RL: Effect of fasting on cocaine-amphetamine-regulated transcript, neuropeptide $\mathrm{Y}$, and leptin receptor expression in the non-human primate hypothalamus. Neuroendocrinology 2006;84:83-93.
55 Robson AJ, Rousseau K, Loudon AS, Ebling FJ: Cocaine and amphetamine-regulated transcript mRNA regulation in the hypothalamus in lean and obese rodents. J Neuroendocrinol 2002;14:697-709.

56 Kalamatianos T, Grimshaw SE, Poorun R Hahn JD, Coen CW: Fasting reduces KiSS-1 expression in the anteroventral periventricular nucleus (AVPV): effects of fasting on the expression of KiSS-1 and neuropeptide $\mathrm{Y}$ in the AVPV or arcuate nucleus of female rats. J Neuroendocrinol 2008;20:1089-1097.

57 Yamada S, Uenoyama Y, Kinoshita M, Iwata K, Takase K, Matsui H, Adachi S, Inoue K, Maeda KI, Tsukamura H: Inhibition of metastin (kisspeptin-54)-GPR54 signaling in the arcuate nucleus-median eminence region during lactation in rats. Endocrinology 2007; 148:2226-2232.

58 Castellano JM, Navarro VM, Fernandez-Fernandez R, Nogueiras R, Tovar S, Roa J, Vazquez MJ, Vigo E, Casanueva FF, Aguilar E, Pinilla L, Dieguez C, Tena-Sempere M: Changes in hypothalamic KiSS-1 system and restoration of pubertal activation of the reproductive axis by kisspeptin in undernutrition. Endocrinology 2005;146:3917-3925.

59 Ludwig M, Bull PM, Tobin VA, Sabatier N, Landgraf R, Dayanithi G, Leng G: Regulation of activity-dependent dendritic vasopressin release from rat supraoptic neurones. J Physiol 2005;564:515-522.

60 Leng G, Caquineau C, Ludwig M: Priming in oxytocin cells and in gonadotrophs. Neurochem Res 2008;33:668-677.

61 Van den Pol AN: Neuropeptide transmission in brain circuits. Neuron 2012;76:98-115. 